\title{
Work Autonomy and Outcomes: Trend of Innovations in Korean Public-sector Organizations
}

\author{
Janiscus Pieter Tanesab \\ Doctoral Candidate in Public Administration \\ Graduate School of Governance, Sungkyunkwan University \\ Seoul-Republic of Korea
}

\begin{abstract}
Modern work environments, including such innovations as remote work-stations and telecommuting employees, require creative approaches to improve the effectiveness of self-management. This paper examines relationships between work autonomy, performance, and public service satisfaction mediated by trends of innovations in publicsector organizations. It aims to describe causal effect of work autonomy on 1) work performance, and 2) public service satisfaction as outcomes through the contribution of innovation on employee management. The study addresses empirical issues in Korean public-sector organizations and concepts of work autonomy, work performance, public service satisfaction and organizational innovations based on self-determination and innovation diffusion theory. Using survey data of Korean Institute of Public Administration (KIPA), the research applied structural equation modeling for the analysis. The results show that work autonomy positively shaped employees' capacities for better work performance development and public service satisfaction. Those components are triggered by the power of competitive innovations by Korean public-sector organizations. The study highlights the importance of people innovation as an influential factor on work autonomy, performance and public service satisfaction. This suggests that organizations need to concern with work autonomy-based innovations for creative work performance and increase service satisfaction for public-sector organizations.
\end{abstract}

Keywords: work autonomy, work performance, public service satisfaction, innovation.

\section{Introduction}

Public-sector organizations have experienced dynamic progress through rapid disruptive technology and innovation in this recent era. And public-sector employees are challenged within their field of work to be more innovative and develop better performance within the organization. To empower public-sector employees, and decentralizing tasks accomplishment, work autonomy is imperative to be strengthened in the organization. Work autonomy is the scope of influence for freedom in which employees have on how and what to do at work as an enabler to broaden capacities and reduce supervisory control (Lopes et al. 2017).

Work autonomy is employees' capabilities to perform their activities without fear of consequences and be able to improve the image, status, or career (Kahn 1990; Javed et al. 2017). And so, commitment to work would come alone due to the loyalties for effective public-services. Previous studies have addressed the effects of work autonomy and employee involvement on skills development (Spector 1986; Haynes et al. 1999; Karasek \& Theorell 1990; De Lange et al. 2003; Van der Doef \& Maes 2010; Gallie 2013; Lopes et al. 2017). The current research depicts the impacts of work autonomy on employee's work outcome development in public-sector organizations. Therefore, values of social dimensions through work performance and service satisfaction are critically pivotal to work autonomy for generating capacities and enhancing employee's well-being for the development of the organization (Kim \& Park 2017).

Work autonomy, likewise, simply deals with how leaders put trust in employees that are more autonomous forms of work (Lopes et al. 2017). This can trigger employee's work engagement and contribution to the growth and provides services with loyalty to society (Aninkan \& Oyewole 2014; Kim \& Park 2017). Scholars also continuously argued that leadership plays a potential role in employee's innovative behavior than other factors (Gerybadze et al. 2010; Javed et al. 2017), and work autonomy is deemed as the hallmark of decentralized activities of public-sector organizations.

Moreover, empowering work autonomy requires creativity and innovation for organizational competitiveness and sustainability. Innovation becomes one of the key success factors for today's organizational development.

It shows up when an employee develops, promotes, and manifests his new concepts into realities as innovative work behavior (Janssen 2000; Javed et al. 2017). Innovative work is performed in a competitive work environment. It is considered intentional creation, based on the introduction and integration of new ideas like idea generation, idea promotion, and idea realization to benefit the existence of the organization (Janssen 2000; Kim \& Park 2017). 
Innovation then is greatly dependent on changes in employees' social behavior in the organization. Scholars have argued that innovative work behavior is the core of useful ideas of employees because it integrates economic, social and psychological aspects for beneficial from organization's status quo through administrative, technological and social changes (West 2002; Rank et al. 2004; West et al. 2004; Orth \&Volmer 2017). It is required by employees to avoid traditional thinking in their routines. Instead, they can deliver new ideas (Kanter 1988; Kessel \& Schults 2012; Javed et al.2017). Thus, it needs a high degree of work autonomy to express freedom of ideas for development in an organization (Foss et al. 2013; Javed et al. 2017). Previous scholars have addressed the role of innovative work behavior on organizational performance (Shanker et al. 2017). However, it is necessary to posit an independent construct i.e. work autonomy, so that organizational innovation can function as a mediator to bridge the work autonomy toward the outcomes i.e. both work performance and public service satisfaction in public-sector organizations.

Innovation is an enabler to improve performance and more responsive to customers in form of social innovation (Osborne 1993; Frederickson 1996; Sorensen \& Torfing 2011; Suh et al. 2018), such as developing knowledge sharing for the organizational development. It deals with the process of exchanging information or interaction and communication, expert knowledge as well, as feed-back to create new things to achieve the intended goals (Cummings 2004; Wang \& Noe 2010; Kim \& Park 2017).

Concerning the empirical circumstances of work autonomy and organizational innovation, South Korea as one of the longest workweeks in advanced countries has experienced kinds of social issues on public-sector employees such as stressful situations while working, lack of time and flexibility to strengthen social bonds or even lack of sleeping time. This problematic situation has been reacted through the Korean government policy implementation of public-employees working hours from 68 to 52 hours per week as an effort to diminish chronic overwork. Then, it was also intended to promote a greater work-life balance. The question is that does it help to improve work performance and increase service satisfaction for public-sector employees?

From this rationale, the current research addressed the effects of work autonomy towards both work performance and public service satisfaction by applying the mediating role of organizational innovation in Korean public-sector organizations. So, the research questions of the study are 1). Is there any association of work autonomy to both work performance and public service satisfaction in the public-sector organization?; 2). Does organizational innovation play the mediating role between work autonomy and both work performance and public service satisfaction in the public-sector organization?

The study was aiming to find out causal relationships between work autonomy to both employee's performance and public service satisfaction; and then, the mediating role of organizational innovation to those latent variables in Korean public-sector organizations. After the entire introduction, the author addressed the theoretical framework concerning previous findings and hypotheses development. Then, in the method section, structural equation modeling was applied for measurement techniques and the analysis for results. The author briefly addressed critical findings and discussion; and in the last part; the author also highlighted theoretical and practical implications and proposals for further studies.

\section{Literature Review and Hypotheses Development}

\subsection{Work Autonomy, Performance, and Public Service Satisfaction}

Work autonomy is the degree of employees' decisions about determining which tasks to perform, and how to plan schedule, design, and implement as daily routines in the organization (Hackman \& Oldham 1975; Orth \& Volmer 2017). It is also deemed as the extent to which employees can develop the influence and practice over their immediate work activities or routines (Lopes et al. 2017).

Work autonomy is about decision making. And so it is simply a nudge of creating environmental conditions to influence employees affording their work choice (Thaler \& Sunstein 2008; Owens et al. 2017). It gives chance to be able to choose and decide which tasks to do, how, and when that means self-determination given at work based on freedom from any type of control. In that sense, work autonomy required flexibility as in which it provides job independence for employees to determine the process and procedure to carry out the job as well (Hackman \& Oldham 1975; Preenen et al. 2017). So, flexibility is greatly devoted to enhancing discretion and responsibility in the work environment (Lopes et al. 2017).

This choice architecture integrates behavioral psychology in shaping decisions of employees' work autonomy and delegating empowerment (Owens et al. 2017). Thus, work autonomy is related to discretion for flexibility at work. In practice, work autonomy is an integral part of the job and forms employees' daily working conditions (March \& Wilkinson 2000; Lopes et al. 2017). Providing employees services with choices would give them the freedom to act well and reach the goal of the organization. It depends on the relational perspectives of autonomy that employee's freedom to deliberate and act in social relationships which they experienced (Mackenzie \& Stoljar 2000; Clifford 2013; Owens \& Cribb 2013; Owens et al. 2017). 
Leaders wish to empower employees to express their work performance through work autonomy in the organization (Lopes et al. 2017). Performance becomes the ultimate measure of values dealing with achievements to support a competitive strategy in an organization (Valmohammadi \& Ahmadi 2015). The effect of power delegation enables employees to constrain their decisions and induce them to increase their performance and reduce tight control. So, having trust in employees both expected and actual trust worthiness like preferences and beliefs (Lopes et al. 2017) are determinants of work autonomy to gain better work performance in public-sector organizations.

Scholars argued that autonomy is sometimes limited to the constructive capacities of making the decision and taking action. Employees' capacities in terms of knowledge, skills, and abilities are believed can improve better performance (Tims et al. 2015; Guan \& Frenkel 2018). So, the main concern is extended through opportunities for employees to practice capacities in 'choice and voice' (Mladenov et al. 2015; Owens et al. 2017). And then, satisfaction in public services can also be deeply acknowledged in terms of its relationship to determinant factors like stress, high control at work, and working conditions (Noor 2011; Arunika \& Kottawatta 2017). Employees need to be empowered to express their freedom and commitment to work for greater work performance and better public service satisfaction in the organization. Work autonomy has been widely studied as s predictor of perceived organizational support (Eisenberger et al. 1999; Rhoades \& Eisenberger 2002; Jong \& Ford 2020). And by applying Self-Determination Theory, a recent study has also addressed the mediation function of autonomy to the relationship between social media usage and employee job satisfaction (Demircioglu 2018). Whereas, the current research addressed work autonomy as the antecedent for the outcomes, i.e. work performance and public service satisfaction in the public-sector, regarding the context of public-sector employees in Korea who are demographically highly educated and innovative in public-sector organizations. Thus, the author addressed assumptions that:

Hypothesis 1a: Work autonomy is positively associated with work performance in public-sector organization.

Hypothesis 1b: Work autonomy is positively associated with public service satisfaction in public-sector organization.

\subsection{Mediating Role of Organizational Innovation}

Work autonomy leads to a sense of responsibility as the increase of employees' motivation which is respectively correlated to the integration of new ideas into creativity (Amabile et al. 1996; Urbach et al. 2010; Fay et al. 2015). It is the independence of team-work operating within the organization. Work autonomy in an organization through team work management can lead to achieve innovation and initiate practical implementation (Fay et al. 2015).

Organizational innovation is considered as a response for the adaptation and implementation of new ideas to the environment of the organization at a certain time of adoption (van de Ven 1986; Amabile, 1996; Damanpour \& Schneider 2006; Fay et al. 2015). Innovation is related to process, product, technology, administrative or structure innovation, people innovation, exploitative innovation, and exploratory innovation (Neck et al. 2017). And so, creativity is a trigger for innovation. This writing is more on administrative, and people innovation that complies with changes in organization and behaviors of employees' work in public-sector organizations. Then, exploratory innovation focuses on risk-taking and freedom of radical thinking. It can bring changes within the organization through a structure, culture, and decision making (Neck et al. 2017).

Turning new ideas into reality, some challenges need to be considered (Klein \& Sorra 1996; Fay et al. 2015) related to complex processes and adaptations within the organization. Innovation goes through matching the integration of ideas into an opportunity as a decision to implement practical routines (Zaltman et al. 1973; Fay et al. 2015). Then, in making an innovative decision, trust is deemed as the hallmark that reduces risks and costs and then promotes self-enforcement to secure the organization from opportunistic behavior. Having generalized trust may lead leaders and managers trustworthy to increase employees' discretion and decentralize in decision making. Nevertheless, a lack of trust may diminish work autonomy and would lead to much more monitoring at work within the organization (Lopes et al. 2017). Thus, work autonomy becomes a determinant aspect of the organizational innovation (Drucker 1999; Preenen et al. 2017) to greater performance and anticipate uncertainties of the competitive environment.

The uniqueness of leader and employees' relationships support the quality of innovative work behavior. In this case, inclusive leadership is fundamental to employees' relationships (Javed et al. 2017). Flexibility practices also facilitate individuals inside the organization to arrange the content of the job (Preenen et al. 2017) without neglecting the goal of the organization. A low level of work autonomy, in contrast, can inversely affect employees' efforts to innovate. Autonomy is likely to be related to innovation developed by employees that required changes in innovative work behavior (Battistelli et al. 2013; Orth \& Volmer 2017). Scholars have repeatedly stated that work autonomy and innovative work behavior perpetuate meaningful variations in employees' daily routines. However, both autonomy and innovation are less explored so far in the public-sector organization (Petrou et al. 2012; Orth \& Volmer 2017). 
Implementation of Innovative ideas and integration of daily work autonomy are as prominent variables that can foster the extend of employee's discretion in designing and choosing the method to complete their tasks (Hackman \& Oldham 1975; Orth \& Volmer 2017). Daily work autonomy and work engagement correlate to innovative work of employees which is more efficacy for creative work (Orth \& Volmer 2017). As scholars found that work autonomy is positively related to innovation (Axtell et al. 2000; Spreitzer 1995; Preenen et al. 2017) and work autonomy is strongly associated with employee innovation as the outcome of the organization (Hammond et al. 2011; Preenen et al. 2017). A recent study has addressed the mediating effect of innovative work behavior on the relationship between organizational climate for innovation and organizational performance (Shanker et al. 2017). This current study posited the organizational innovation as the mediator to the relationship of work autonomy on both work performance and public service satisfaction in public-sector organizations. The study considered organizational innovation as a critical component that plays a role to link public employees' freedom to work in flexible conditions and greater innovation in public-sector organizations. Therefore, it was assumed that:

Hypothesis 2a: Organizational innovation positively mediates the relationships of work autonomy and work performance in public-sector organization.

Hypothesis 2b: Organizational innovation positively mediates the relationships of work autonomy and public service satisfaction in public-sector organization.

\subsection{Organizational Innovation, Work Performance, and Public Service Satisfaction}

Innovation appears as the initiation of the public sector organizations to bring new changes to the performance and service satisfaction in the organization. It is from the integration of new ideas to proceed with products or services (Crossan \& Apaydin 2010; Suh et al. 2018). Organizational innovation is a well-known action for changes through creativity and development with the organization. Successful organizational innovation cannot be separated from employees' commitment and dedicated trust to contribute and stay with the organization. Though high risks situations are encountered, employees keep their trust to serve the organization in innovative ways for achieving better public service satisfaction (Buchele \& Christiansen 1999a; Preenen et al. 2017). Like work performance, public service satisfaction is also an imperative outcome in public-sector organizations. Work satisfaction is a pleasurable state resulting from the appraisal gained in the work as well as work experiences (Locke 1976; Bayraktar et al. 2017). Abilities to learn new things and develop cooperation greatly contribute to job satisfaction (Daft 2008; Bayraktar et al. 2017). Therefore, innovation is deemed to support greater impacts on work performance and the achievement of public service satisfaction.

Innovation diffusion is a strong theory to predict the spread of innovation in the social system. It is an idea and practice that individuals perceived a new change in time since it is first used or discovered (Rogers 1983; Wani \& Ali 2015). Innovation diffusion focuses on persuading individuals to change behaviors, so people become better fits for the needs of individuals and groups (Wani \& Ali 2015). The diffusion of innovation can only develop when a social system accepts it as an innovation, share, and communicate the information within and among the system of institutions (Rogers 2003; Wani \& Ali 2015).

In terms of innovative work performance, employees need the support of a work environment like leadership factor as a key agent of change that perform new ideas to support the employee's innovation (De Jong \& Den Hartog 2010; Javed et al. 2017). Social and environmental changes thus push innovation for reaching better employees' work performance. Previous scholars stated that engaged employees are more likely to put attention to work-related knowledge and innovative work behavior which influences the human dimension of organizational development (Kim \& Park 2017). Innovative work may boost employees' efforts to implement individual as well as organizational innovation across days (Orth \& Volmer 2017).

Therefore, it is important to promote innovative work performance across employees' routines. Internal flexibility work builds employees' trust, feeling, and commitment to job practices that can enhance organizational innovation and bear productivity (Preenen et al. 2017). Flexibility to work also improves the quality of work-life through creativity and new ideas that reduce repetitive works, monotonous for the employees' performance, and organizational improvements (Kelliher \& Riley 2003; Martínez-Sánchez et al. 2008; Preenen et al. 2017). Workrelated innovation is posited as a novel behavior which can impact on performance (Guan \& Frenkel 2018) and dedicate public service satisfaction.

Employees' learning process in an organization contributes to competitive advantage based on the emerged experiences and practical learning for organizational innovation (Gherardi et al.1998; Van der Sluis 2004; Preenen et al. 2017). Better public services help create welfare sustainability for the achievement of good economic, environmental, and social attainment in a collective manner (Hart \& Milstein 2003; Spreitzer et al. 2012; Kim \& Park 2017). Scholars argued that innovation has been widely taken as the outcome of collaboration based on knowledge sharing for the performance of organizational innovation (Lee et al. 2005; Preenen et al. 2017). This study addressed work performance and public service satisfaction as outcomes of public-sector employees' sustainable work development. 
Concerning the suggestion of Sonmes and Yildirim (2018) to investigate the relationship between employees (nurses) innovative work behavior and working performance, as what Shanker et al. (2017) have studied previously, - thus, regardless of its position as the mediator in this study a, the author also tested the relationship of the organizational innovation as the interim antecedent to the outcomes, i.e. work performance and public service satisfaction in public-sector organization. So, it was hypothesized that:

Hypothesis 3a: Organizational innovation is positively associated with work performance in public-sector organization.

Hypothesis 3b: Organizational innovation is positively associated with public service satisfaction in public-sector organization.

Figure 1:

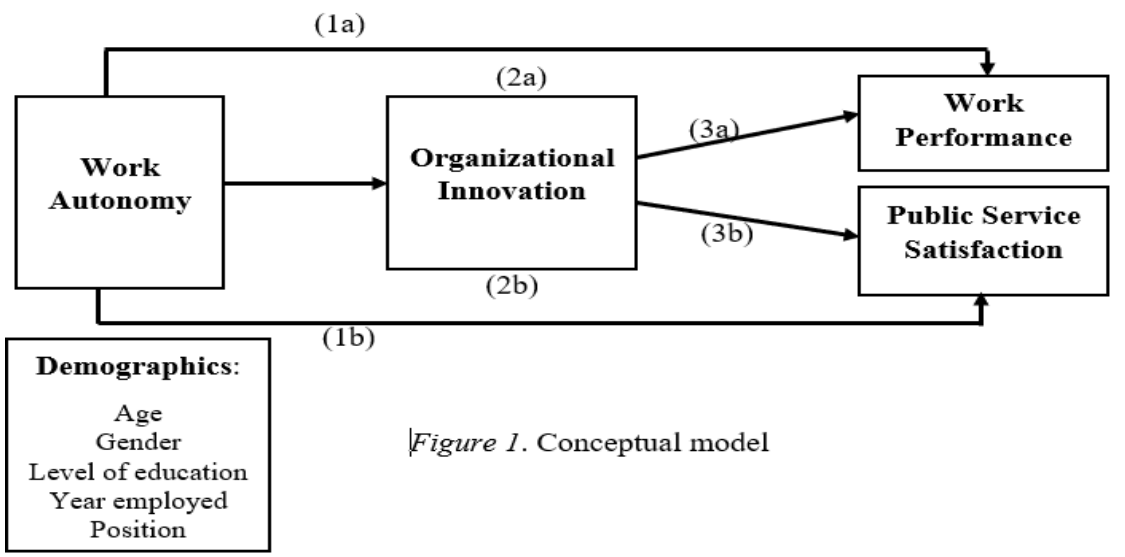

\section{Research Methods}

\subsection{Research Setting and Data Collection}

The study applied survey data collected from the Public Employee Perception Survey of the Korean Institute of Public Administration (KIPA) 2016. It was applied to 42 central administrative agencies that integrated 2070 respondents employed in 17 local governments in South Korea.

A total population of 2070 valid responses participated to conduct the study as a sampling population, involving 1 , $340(64.7 \%)$ participants as civil servants from central administrations, while $730(35.3 \%)$ were from local governments. The survey questionnaire comprises 14 items in total derived from those latent constructs of work autonomy, organizational innovation, work performance, and public service satisfaction. In the sample, there are 63.4 percent male and 36.6 percent female. The ratio of gender in the sample delineated the male-female ratio addressed by the Korean Ministry of Gender and Family in 2015 (i.e., 71.3\% male, 28.7\% female).

The majority of levels of respondents' education are bachelor's degree $(72.4 \%)$ and master's degree (17.6\%). Then, the average age of the total respondents was 40 years.

For the marital status, 74.6 percent were married, and 24.9 percent were single. In terms of carrier ranking, mostly respondents belong to civil service grade 7 (28.8\%), grade 6 (28.8), and grade 5 (22.6\%). Table 1 depicted the characteristics of the sample in detail. Those items are in the Korean language, while for the sake of this study, they are translated into English. Table 1 addressed the detailed characteristics of the sample $(n=2070)$. 
Table 1. Sample Characteristics

\begin{tabular}{|c|c|}
\hline Variables & $\%$ \\
\hline \multicolumn{2}{|l|}{ Gender } \\
\hline Male & 63.4 \\
\hline Female & 36.6 \\
\hline \multicolumn{2}{|l|}{ Age (years) } \\
\hline $20-29$ & 9.2 \\
\hline $30-39$ & 39.5 \\
\hline $40-49$ & 38.4 \\
\hline 50 and above & 12.9 \\
\hline \multicolumn{2}{|l|}{ Current Position } \\
\hline Grade 9 & 4.9 \\
\hline Grade 8 & 7.8 \\
\hline Grade 7 & 28.8 \\
\hline Grade 6 & 28.8 \\
\hline Grade 5 & 22.6 \\
\hline Grade 4 & 5.7 \\
\hline Grade 3 & 1.3 \\
\hline Grade 2 & 0 \\
\hline Grade 1 & 0 \\
\hline \multicolumn{2}{|c|}{ Current Educational Attainment } \\
\hline High School or less & 2.9 \\
\hline College (2-3 years) & 5.5 \\
\hline Bachelor's Degree & 72.4 \\
\hline Master's Degree & 17.6 \\
\hline Doctorate & 1.6 \\
\hline \multicolumn{2}{|l|}{ Type of Organization } \\
\hline Central & 64.7 \\
\hline Local & 35.3 \\
\hline
\end{tabular}

The designed constructs generated multiple item scales which were measured by applying the Likert scale. Each item was ranged from points of strongly disagree (1) to strongly agree (5).

Then, the author applied exploratory factor analysis (EFA) to identify factors and maximize their variances based on the entire data; and confirmatory factor analysis (CFA) to test those hypotheses by looking at underlying relationships among measured variables. Then, structural equation modeling was applied to find the causal-effect relationships between those measured variables and latent constructs based on the given hypotheses.

In work autonomy, four items were applied from the study to measure employees' choice, decision, flexibility work adjustment, and determination of work. Those items were expressed as follows: "I can participate in making a decision that can affect the content of my work; I have the choice of how to do the work based on procedures; I can adjust my work speed and deadline; I can determine the order and priority of my work". So, the value of Cronbach's alpha achieved for those factors of work autonomy was .828 .

Organizational innovation was measured using a five-item scale. Those items encompassed: "Our organization is flexible and responds instantly for changes; Our organization accepts some risk for innovation; I develop new ideas to solve problems that arise during work; I try to create/ apply a new and original way of doing business; Change in our organization usually has a positive effect". The result of those factors counted Cronbach's alpha for organizational innovation was .875. 
Furthermore, work performance was measured by having three items. They were noted as follows: "I am achieving the expected performance in my work; I attain the required results from the organization, other organizations, and stakeholders involved in my duties; I fulfill my responsibilities for my performance". Thus, Cronbach's alpha for work performance factors was .871 .

Public service satisfaction was measured in four items. They were stated as follows: "Public officials are socially highly rated; I am satisfied with the stability of public service; I am satisfied with the prospect of public service; I am generally satisfied with work as a civil servant”. The result perceived through Cronbach's alpha was .824.

The effects of demographic factors such as employee's age, gender, education, year of employment, and tenure which could affect those constructs and variables were also controlled in this study. The result showed consistency among those demographic aspects as well, like the age indicating longer time duration of work on the work performance.

\subsection{Analysis and Measurement Model}

Structural equation modeling was applied in a two-step approach, firstly by estimating the measurement model, and then estimating the structural model. Those regressions were aimed to minimize the standard error by applying maximum likelihood with strength of standard errors. Then, the integration of CFA to assess factor structure, reliability, and validity for those constructs as latent variables.

Table 2. Findings of Exploratory Factor Analysis

\begin{tabular}{|c|c|c|c|c|c|}
\hline \multicolumn{6}{|c|}{ Pattern Matrix ${ }^{a}$} \\
\hline \multirow[t]{2}{*}{ Items } & \multicolumn{4}{|c|}{ Factors } & \multirow{2}{*}{$\begin{array}{c}\text { Cronbach Alpha } \\
5\end{array}$} \\
\hline & 1 & 2 & 3 & 4 & \\
\hline OrgInnov_2 & .867 & & & & \\
\hline OrgInnov_1 & .866 & & & & \\
\hline OrgInnov_3 & .793 & & & & .875 \\
\hline OrgInnov_4 & .636 & & & & \\
\hline OrgInnov_5 & .584 & & & & \\
\hline PublicServSat_2 & & .843 & & & \\
\hline PublicServSat_4 & & .813 & & & .824 \\
\hline PublicServSat_3 & & .739 & & & \\
\hline PublicServSat_1 & & .561 & & & \\
\hline Autonomy_3 & & & .809 & & \\
\hline Autonomy_4 & & & .775 & & .828 \\
\hline Autonomy_2 & & & .747 & & \\
\hline Autonomy_1 & & & .597 & & \\
\hline WorkPerf_3 & & & & .873 & \\
\hline WorkPerf_2 & & & & .836 & .871 \\
\hline WorkPerf_1 & & & & .792 & \\
\hline \multicolumn{6}{|c|}{$\begin{array}{l}\text { Extraction Method: Maximum Likelihood. } \\
\text { Rotation Method: Promax with Kaiser Normalization }{ }^{\text {a }} \\
\text { Rotation converged in } 5 \text { iterations. }\end{array}$} \\
\hline
\end{tabular}

Measurement technique was modelled in factor loading which was ranged from .56 to .87 , and it was indicated if the minimum threshold was above .50. The measurement of Kaiser-Meyer-Olkin (KMO) of sampling adequacy was equivalent to $.843(p<.000)$.

Then, in conducting confirmatory factor analysis, author addressed the difference among latent variables found in the model to a proper fit among the constructed model. It was found if the comparative fit index (CFI) was .967 (>.95); the standard root mean residual (SRMR) was .059 (<.08); and the root mean square of approximation (RMSEA) was .045 (<.08); PClose was 0.924 (>.05). So, it can be argued that these results were assumed as excellent as long as they were greater than the minimum threshold for each. Measurement on discrimination validity of constructs model found that internal consistency index (CR) was greater than .86, which is above the threshold of .70, and the average variance extracted was above .70, which is above the threshold of .50 .

Table 3. Model Validity Measures

\begin{tabular}{lll}
\hline Variables & CR & AVE \\
\hline 1. Work Autonomy & 0.864714 & 0.709175 \\
2. Organizational Innovation & 0.880407 & 0.721076 \\
3. Work Performance & 0.91241 & 0.802321 \\
4. Public Service Satisfaction & 0.90132 & 0.801216 \\
\hline
\end{tabular}


Furthermore, the correlation coefficient in terms of descriptive statistics (mean and standard deviation) between constructs model showed that the correlation among variables are relatively strong $(\mathrm{p}<.001)$. Therefore, it can be stated that work autonomy is strongly correlated with both work performance and public service satisfaction; and the mediating role of organizational innovation to the relationships between those latent variables.

\section{Figure 2: Confirmatory Factor Analysis}

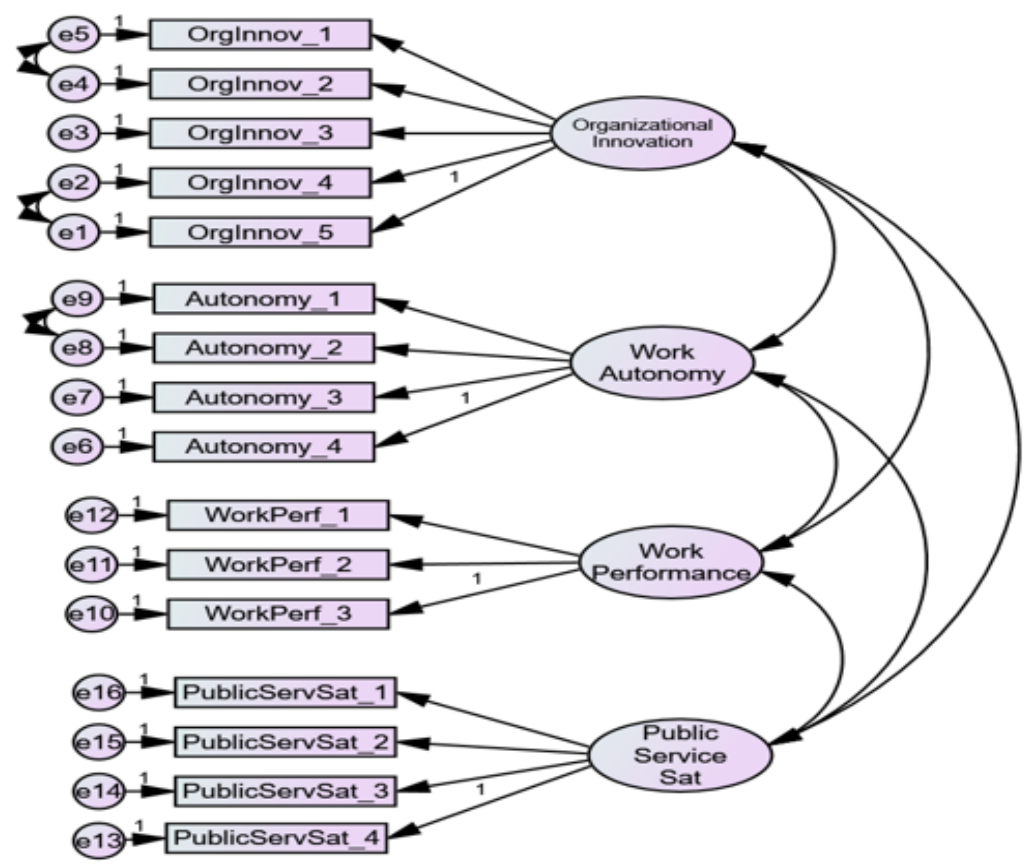

\section{Hypothesis Testing and Discussion of the Results}

Regarding the measure of the stated assumptions, the aggregation of estimation and fit indices were applied in the structural equation modeling (SEM). It is depicted in figure (3).

Figure 3: Structural Equition Modelling

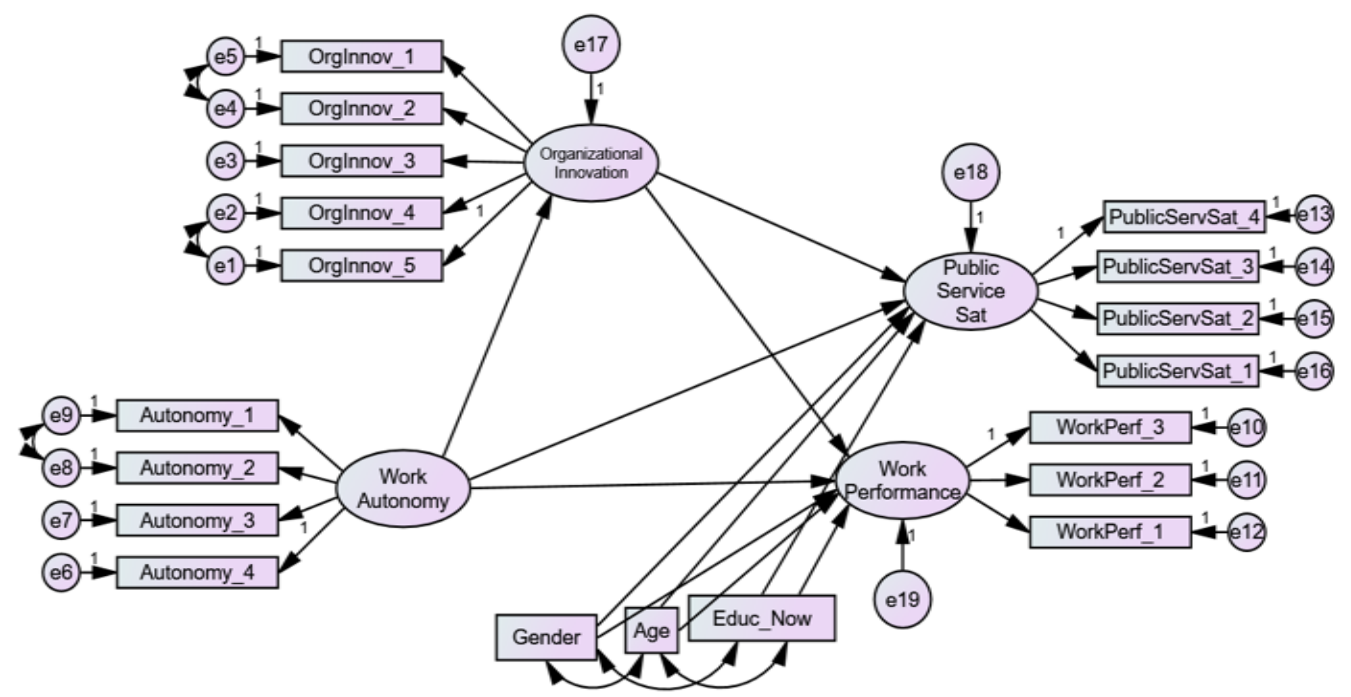

The presented results revealed a good fit index: $\mathrm{CFI}=.967$; RMSEA $=.045$; and CMIN/DF $=2.458$. Those measures are found as fulfilling the minimum thresholds and thus, acceptable, and excellent treatments as depicted on the entire table (4). 
Table 4. Model Fit Measures

\begin{tabular}{llll}
\hline Measure & Estimate & Threshold & Interpretation \\
\hline CMIN & 339.196 & -- & -- \\
DF & 138 & -- & -- \\
CMIN/DF & 2.458 & Between 1 and 3 & Excellent \\
CFI & 0.967 & $>0.95$ & Acceptable \\
SRMR & 0.059 & $<0.08$ & Acceptable \\
RMSEA & 0.045 & $<0.06$ & Acceptable \\
P Close & 0.924 & $>0.05$ & Acceptable \\
\hline
\end{tabular}

From the results of the measurement, it is argued that the findings were considered suitable to the depicted model, and the given data. And so the study found positive relationships among those variables; in this matter, there is a positive direct relationship between work autonomy and outcomes, i.e. both work performance, and public service satisfaction of the Korean public-sector organizations. It essentially indicates that autonomy allows much more freedom and flexibility to the Korean public-sector employees to develop their capacities for better work performance and public service satisfaction. In practice, Mrayyan (2014; Sonmez \& Yildirim 2020) similarly conducted a study on nurses as public employees, - found that autonomy allows nurses to express their expertise and skills to increase care outcomes, job satisfaction, and retention. Other previous scholars also argued that working in an environment where autonomy exists, public employees might experience more interests and a sense of willingness to address novel things, and more productive (Amabile et al. 1996; Si \& Wei 2012; Shanker et al. 2017). In this regard, greater work performance and public service satisfaction admittedly depend on freedom and flexibility of employees to work, in which absolutely through innovative behavior, service motivation and commitment of individual employees; - so individualized considerations play a critical role of the work autonomy toward work outcomes (Jong \& Ford 2020), - and institutions included leadership aspect as well are also pivotal in public-sector organizations. Therefore, from this study, the stated assumptions of hypotheses 1a,b were supported.

Subsequently, the results revealed that organizational innovation positively has a mediating role in the relationships of work autonomy and both work performance and public service satisfaction. The support of the organizational innovation is not just about the sufficient physical technological infrastructure, but also it is tightly determined by capable public employees and process innovation. For instance, a study of Demircioglu (2018) about the effect of social media use on job satisfaction, showed that social media has an indirect effect on job satisfaction.

Thus, through innovative work behavior, greater human resource autonomy could contribute to having better human resource inputs such as relevant knowledge and skills to fit the job for better outcomes of public services (Nielson 2014; Song et al. 2020). And then a high level of professional autonomy might devote greater innovative outputs through the support of innovative work behavior of the employees (Sonmes \& Yildirim 2018) in publicsector organizations. From the mediating effect of the organizational innovation, then, the result supported hypothesis $2 \mathrm{a}, \mathrm{b}$.

Then, the result also showed that organizational innovation had positive relationships with both work performance and public service satisfaction. Rationally, public-sector employees have perpetuated their innovative work behaviors to achieve greater service satisfaction and better work performance. Bottom-up innovation, i.e. employees' capacities, is an essential point associated with public employees' work satisfaction (Demircioglu 2020), and service performance. And it is supported by a sufficient innovative organizational environment such as innovative human resource capacities, technological advancement, and agile process through smart work systems in public-sector organizations. Scholars also argued that employees' satisfaction through public service satisfaction could strongly influence employees' work performance in public-sector organizations (Lasisi et al. 2020). And so, the stated assumption (hypothesis 3a,b) was supported as well. 
Table 5. Regression Weights of SEM

\begin{tabular}{|c|c|c|c|c|c|c|c|}
\hline Outcomes & & Antecedents & Estimate & S.E. & C.R. & $\mathrm{P}$ & Label \\
\hline $\begin{array}{l}\text { Organizational } \\
\text { Innovation }\end{array}$ & $<--$ & Work Autonomy & .328 & .035 & 9.307 & $* * *$ & \\
\hline $\begin{array}{l}\text { Public Service } \\
\text { Satisfaction }\end{array}$ & $<--$ & $\begin{array}{l}\text { Organizational } \\
\text { Innovation }\end{array}$ & .412 & .061 & 6.777 & $* * *$ & \\
\hline Work Performance & $<--$ & $\begin{array}{l}\text { Organizational } \\
\text { Innovation }\end{array}$ & .152 & .055 & 2.774 & .006 & \\
\hline Work Performance & $<--$ & Work Autonomy & .301 & .042 & 7.209 & $* * *$ & \\
\hline $\begin{array}{l}\text { Public Service } \\
\text { Satisfaction }\end{array}$ & $<--$ & Work Autonomy & .101 & .042 & 2.401 & .016 & \\
\hline Work Performance & $<--$ & Gender & -.100 & .047 & -2.141 & .032 & \\
\hline Work Performance & $<---$ & Age & .012 & .003 & 4.257 & $* * *$ & \\
\hline Work Performance & $<--$ & Education & .044 & .032 & 1.389 & .165 & \\
\hline $\begin{array}{l}\text { Public Service } \\
\text { Satisfaction }\end{array}$ & $<--$ & Gender & .091 & .049 & 1.866 & .062 & \\
\hline $\begin{array}{l}\text { Public Service } \\
\text { Satisfaction }\end{array}$ & $<--$ & Age & -.001 & .003 & -.503 & .615 & \\
\hline $\begin{array}{l}\text { Public Service } \\
\text { Satisfaction }\end{array}$ & $<--$ & Education & .101 & .033 & 3.045 & .002 & \\
\hline
\end{tabular}

\section{Conclusion}

The study was applied to measure the causality of the relationships of work autonomy to both public service satisfaction, and work performance in public-sector organizations. Work autonomy perpetuated a significant influence on the development of public service satisfaction, and work performance in public-sector organizations. Public employees who posit more autonomy in their work behavior are more likely to work favorably in a more supported working condition; - However, those with low perceived autonomy might attribute unfavorable working conditions (Jong \& Ford 2020) that impact on the low work performance, and lack of public service satisfaction in public-sector organizations. Therefore, granting more autonomy to public sector employees can improve the organizational performance, efficiency, effectiveness which simultaneously increase public service satisfaction (Stazyk 2016; Demircioglu 2018), and more than that, it can develop equality and equity of public services.

Organizational innovation is a pivotal mediating factor in the association between work autonomy and those organizational outcomes. Organizational innovation positively had a mediating role in the relationships between work autonomy and both work performance, and public service satisfaction in Korean public-sector organizations. Public-sector employees who have freedom and flexibility to work under relevant levels of autonomy tend to be more innovative, compared to those who lack work autonomy in public services (Sonmes \& Yildirim 2018). And so work autonomy posits a huge effect on public employees' innovative behavior (Krause 2007; Shanker et al. 2017) of the organizational innovation, which can result in greater work performance and public service satisfaction in public-sector organizations.

Then, organizational innovation also affected both organizational performance and public service satisfaction. It is empirical that here now in Korea, greater performance perpetuated by the Korean public employees is significantly determined by their advanced organizational innovation in public-sectors. Scholars have also argued that innovations affect both individuals and organizational outcomes (Walker et al. 2011; Demircioglu 2020). Organizational innovation enhances the outcomes, i.e. services or products for greater work performance (Azar \& Ciabuschi 2017) in public-sector organizations. In short, the causal effect relationships of work autonomy to both work performance and public service satisfaction is contributable. Then, through the mediating role of organizational innovation, public employees are more autonomous and produce better services in organizational outcomes, and are getting more advance in the Korean public-sector organizations.

\section{Theoretical and Practical Implications}

The results of the study are consistent with previous findings showing causalities in an association between work autonomy and employee work performance in public-sector organizations. Work autonomy posits as a critical component for creating better employee's working conditions (March \& Wilkison 2000; Lopes et al. 2017). From this study, work autonomy contributes significantly to the increased of better work performance of public employees in Korean public-sector organizations. Furthermore, the significant association of work autonomy to public service satisfaction was also contributable. 
Similarly, scholars argued that work autonomy creates a suitable environment that impacts satisfaction in public services to avoid unintended circumstances like stress, high control at work, and other unintended working conditions (Noor 2011; Arunika \& Kottawatta 2015). Therefore, the current research fully supports the principle of Self-Determination Theory (SDT), employed to support public employees' choices and flexibilities to work in public-sector organizations (Demircioglu 2020). Practically, the finding implied that work autonomy addressed freedom and flexibility of work to improve satisfied capacities within public sector organizations.

Organizational innovation subsequently showed a pivotal mediating role for the association of work autonomy to work performance as well as public service satisfaction in Korean public-sector organizations. Previous research also found that innovative ideas and work autonomy are prominent variables to foster the extent of employees' freedom in designing and choosing the method to complete their tasks for better work performance (Hackman \& Oldham 1975; Orth \& Volmer 2017). The findings also support the principle of diffusion of innovation that works autonomy toward greater work performance can only develop when a social system accepts innovation and share or transmit the information inside and among institutions (Rogers 2003; Wani \& Ali 2015). Therefore, organizational innovation in a creative atmosphere could improve employees' work performance and service satisfaction for organization development. Organizational innovation brings new changes for performance and service satisfaction because of the integration of new ideas to proceed with products or services (Crossan \& Apaydin 2010; Suh et al. 2018). And so, referring to the result, work autonomy and organizational innovation put pivotal contribution onto work performance and public service satisfaction in Korean public-sector organizations.

\section{Limitations and Recommendations}

Although the author found significant results, the study still encountered some limitations. The research just considered the aspect of work autonomy as the antecedent in this study due to its urgency in public-sector organizations. Further research may integrate other constructs of social issues in public sectors like the trend of leadership's influence, organizational commitment, work-life balance, and so forth.

The study was also limited to public-sector employees in the public-sector organization. Thus, it was suggested to extend the research to another locus of study and dimensions of innovation in public administration. Then, it is recommended to modify and integrate other variables to develop the model regarding the contexts in public-sector organizations.

Lastly, the study was conducted using survey data; In order to find an in-depth understanding, it would be necessary to integrate progressive mixed-approach and instruments, such as interviews applied to current public employees and so forth., While also it is necessary to apply the updated version of survey data in which the current survey data is considered lacking to up to date. It is suggested that to achieve effective outcomes, work autonomy should dedicate freedom of choice to public employees to express novel ideas, skills, and creativity in public-sector organizations.

\section{References}

Amabile TM, Conti R, Coon H et al. (1996). Assessing the work environment for creativity. Academy of Management Journal 39(5): 1154-1184.

Aninkan, D.O. \& Oyewole, A.A. (2014). The influence of individual and organizational factors on employee engagement. Int. J. Dev. Sustain. 3,1381-1392.

Arunika, M. M. A., \& Kottawatta, H. (2017). The Effect of Work Life Balance on Employee Job Satisfaction among Non-Executives in the Public Banking Sector in Colombo District. Human Resource Management Journal, 3(1).

Axtell CM, Holman DJ, Unsworth KL et al. (2000). Shop floor innovation: Facilitating the suggestion and implementation of ideas. Journal of Occupational and Organizational Psychology 73(3): 265-285.

Azar, G., \& Ciabuschi, F. (2017). Organizational innovation, technological innovation, and export performance: The effects of innovation radicalness and extensiveness. International Business Review, 26(2), 324-336.

Battistelli, A., Montani, F., \& Odoardi, C. (2013). The impact of feedback from job and task autonomy in the relationship between dispositional resistance to change and innovative work behaviour. European Journal of Work and Organizational Psychology, 22, 26-41.

Bayraktar, C. A., Araci, O., Karacay, G., \& Calisir, F. (2017). The mediating effect of rewarding on the relationship between employee involvement and job satisfaction. Human Factors and Ergonomics in Manufacturing \& Service Industries, 27(1), 45-52.

Buchele R and Christiansen J. (1999a). Labor relations and productivity growth in advanced capitalist economies. Review of Radical Political Economics 31(1): 87-110.

Clifford, D. (2013). Ethics, politics and the social professions: Reading Iris Marion Young. Ethics and Social Welfare, 7(1), 36-53.

Crossan, M. M., \& Apaydin, M. (2010). A multi-dimensional framework of organizational innovation: A systematic review of the literature. Journal of Management Studies, 47, 1154-1191. 
Cummings, J.N. (2004). Work Groups, Structural Diversity, and Knowledge Sharing in a Global Organization. Manag. Sci. 50, 352-364.

Daft, R. (2008). New era of management (9th ed.). Mason, OH: South Western/ Cengage Learning.

Damanpour, F. (1991). Organizational innovation: A meta-analysis of effects of determinants and moderators. The Academy of Management Journal, 34, 555-590.

Damanpour, F. and Schneider, M. (2006). Phases of the Adoption of Innovation in Organizations: Effects of Environment, Organization and Top Managers. British Journal of Management, 17, 215-36.

De Jong, J., \& Den Hartog, D. (2010). Measuring innovative work behaviour. Creativity and Innovation Management, 19(1), 23-36.

De Lange A, Taris T, Kompier M. et al. (2003). The very best of the millennium. Journal of Occupational Health Psychology 8(4): 282-305.

Demircioglu, M. A. (2018). Examining the effects of social media use on job satisfaction in the Australian public service: Testing self-determination theory. Public Performance \& Management Review, 41(2), 300-327.

Demircioglu, M. A. (2020). Sources of Innovation, Autonomy, and Employee Job Satisfaction in Public Organizations. Public Performance \& Management Review, 1-32.

Drucker P. (1999). Knowledge-worker productivity: The biggest challenge. California Management Review 41(2): 79-94.

Eisenberger, R., Rhoades, L., \& Cameron, J. (1999). Does pay for performance increase or decrease perceived selfdetermination and intrinsic motivation? Journal of Personality and Social Psychology, 77, 1026-1040.

Fay, D., Shipton, H., West, M. A., \& Patterson, M. (2015). Teamwork and organizational innovation: The moderating role of the HRM context. Creativity and Innovation Management, 24(2), 261-277.

Foss, L., Woll, K., \&Moilanen, M. (2013). Creativity and implementations of new ideas: Do organizational structure, work environment and gender matter? International Journal of Gender and Entrepreneurship, $5(3), 298-322$.

Frederickson, H. G. (1996). Comparing the reinventing government movement with the new public administration. Public Administration Review, 56, 263-270.

Gallie D. (2013). Direct participation and the quality of work. Human Relations 66(4): 453-473.

Gherardi S, Nicolini D and Odella F. (1998). Toward a social understanding of how people learn in organizations the notion of situated curriculum. Management Learning 29(3): 273-297.

Gerybadze, A., Hommel, U., Reiners, H. W., \& Thomas chewski, D. (Eds). (2010). Introduction: Managing innovation in turbulent times. In Innovation and international corporate growth (pp. 1-7). Heidelberg: Springer Berlin.

Guan, X., \& Frenkel, S. (2018). How HR practice, work engagement and job crafting influence employee performance. Chinese Management Studies.

Hackman JR and Oldham GR. (1975). Development of the job diagnostic survey. Journal of Applied Psychology 60(2): 159-170.

Hammond MM, Neff NL, Farr JL et al. (2011). Predictors of individual-level innovation at work: A meta-analysis. Psychology of Aesthetics, Creativity, and the Arts 5(1): 90-105.

Hart, S.L.; Milstein, M.B. Creating sustainable value. Acad. Manag. Exec. (2003). 17, 56-67.

Haynes C, Wall T, Bolden R et al. (1999). Measures of perceived work characteristics for health services research: Test of a measurement model and normative data. British Journal of Health Psychology 4(3): 257-275.

Janssen, O. (2000). Job demands, perceptions of effort- reward fairness and innovative work behaviour. Journal of Occupational and Organizational Psychology, 73(3), 287-302.

Javed, B., Naqvi, S. M. M. R., Khan, A. K., Arjoon, S., \& Tayyeb, H. H. (2017). Impact of inclusive leadership on innovative work behavior: The role of psychological safety. Journal of Management \& Organization, 120.

Jong, J., \& Ford, M. (2020). An Exploration of the Relationship Between Autonomy Congruence, Perceived Supervisor Individualized Consideration, and Employee Outcomes. Review of Public Personnel Administration, 0734371X20917185.

Kahn, W. A. (1990). Psychological conditions of personal engagement and disengagement at work. Academy of Management Journal, 33(4), 692-724.

Kanter, R. M. (1988). Three tiers for innovation research. Communication Research, 15(5), 509-523.

Karasek R and Theorell T. (1990). Healthy Work: Stress, Productivity and the Reconstruction of Work Life. New York: Basic Books.

Kelliher C and Riley M. (2003). Beyond efficiency: Some by-products of functional flexibility. The Service Industries Journal 23(4): 98-113.

Kessel, M., Kratzer, J., \& Schultz, C. (2012). Psychological safety, knowledge sharing, and creative performance in healthcare teams. Creativity and Innovation Management, 21(2), 147-157. 
Kim, W., \& Park, J. (2017). Examining structural relationships between work engagement, organizational procedural justice, knowledge sharing, and innovative work behavior for sustainable organizations. Sustainability, 9(2), 205.

Klein, K.J. and Sorra, J.S. (1996). The Challenge of Innovation Implementation. Academy of Management Review, $21,1055-80$.

Krause, T. (2007). The effective safety leader: Personality, values and emotional commitment. Occupational Hazards, 69(9), 24.

Lasisi, T. T., Ozturen, A., Eluwole, K. K., \& Avci, T. (2020). Explicating innovation-based human resource management's influence on employee satisfaction and performance. Employee Relations: The International Journal.

Lee K, Lee S and Kang I. (2005). KMPI: Measuring knowledge management performance. Information and Management 42(3): 469-482.

Locke, E. (1976). The nature and causes of job satisfaction. In M. Dunnette (Ed.), Handbook of industrial and organizational psychology (pp. 1297-1349). Chicago, IL: Rand McNally.

Lopes, H., Calapez, T., \& Lopes, D. (2017). The determinants of work autonomy and employee involvement: A multilevel analysis. Economic and Industrial Democracy, 38(3), 448-472.

Mackenzie, Catriona, and Natalie Stoljar, eds. (2000). Relational Autonomy: Feminist Perspectives on Autonomy, Agency and the Social Self. Oxford: Oxford University Press.

March M and Wilkinson A. (2000). Direct participation. In: Bach S and Sisson K (eds) Personnel Management: A Comprehensive Guide to Theory and Practice. Oxford: Blackwell.

Martínez-Sánchez A, Vela-Jiménez MJ, Pérez-Pérez M and de-Luis-Carnicer P. (2008). Workplace flexibility and innovation: The moderator effect of inter-organizational cooperation. Personnel Review 37(6): 647-665.

Mladenov, Teodor, John Owens, and Alan Cribb. 2015. "Personalisation in Disability Services and Healthcare: A Critical Comparative Analysis." Critical Social Policy.

Mrayyan, M.T. (2004), "Nurses' autonomy: influence of nurse managers' actions", Journal of Advanced Nursing, Vol. 45 No. 3, pp. 326-336.

Neck, Christopher, P., Houghton, Jeffery, D and Murray, Emma, L. (2017). Organizational Behavior. London: SAGE publication.

Noor, KM. (2011). 'Work Life Balance and Intention to leave among academics in Malaysian Public Higher Education Institutions,' Internal Journal of Business and Social science, vol. 2, no. 11.

Orth, M., \& Volmer, J. (2017). Daily within-person effects of job autonomy and work engagement on innovative behaviour: The cross-level moderating role of creative self-efficacy. European Journal of Work and Organizational Psychology, 26(4), 601-612.

Osborne, D. (1993). Reinventing government. Public Productivity \& Management Review, 16, 349-356. doi:10.1136/bmj.308.6938.1247a.

Owens, J., Mladenov, T., \& Cribb, A. (2017). What justice, what autonomy? The ethical constraints upon personalisation. Ethics and Social Welfare, 11(1), 3-18.

Owens, John, and Alan Cribb. (2013). "Beyond Choice and Individualism: Understanding Autonomy for Public Health Ethics." Public Health Ethics 6 (3): 262-271.

Petrou, P., Demerouti, E., Peeters, M. C. W., Schaufeli, W. B., \& Hetland, J. (2012). Crafting a job on a daily basis: Contextual correlates and the link to work engagement. Journal of Organizational Behavior, 33, 1120 1141.

Preenen, P. T., Vergeer, R., Kraan, K., \& Dhondt, S. (2017). Labour productivity and innovation performance: The importance of internal labour flexibility practices. Economic and Industrial Democracy, 38(2), 271-293.

Rank, J., Pace, V. L., \& Frese, M. (2004). Three avenues for future research on creativity, innovation, and initiative. Applied Psychology: An International Review, 53, 518-528.

Rhoades, L., \& Eisenberger, R. (2002). Perceived organizational support: A review of the literature. Journal of Applied Psychology, 87, 698-714.

Rogers, E. M. (1983). Diffusion of innovations. Third edition. New York. Free Press

Rogers, E.M. (2003). Diffusion of innovations. Fifth edition. New York: Free Press

Shanker, R., Bhanugopan, R., Van der Heijden, B. I., \& Farrell, M. (2017). Organizational climate for innovation and organizational performance: The mediating effect of innovative work behavior. Journal of Vocational Behavior, 100, 67-77.

Si, S., \& Wei, F. (2012). Transformational and transactional leaderships, empowerment climate, and innovation performance: A multilevel analysis in the Chinese context. European Journal of Work and Organizational Psychology, 21(2), 299-320.

Sönmez, B., \& Y1ldırım, A. (2019). The mediating role of autonomy in the effect of pro-innovation climate and supervisor supportiveness on innovative behavior of nurses. European Journal of Innovation Management.

Song, M., An, S. H., \& Meier, K. J. (2020). Quality standards, implementation autonomy, and citizen satisfaction with public services: cross-national evidence. Public Management Review, 1-23. 
Sørensen, E., \& Torfing, J. (2011). Enhancing collaborative innovation in the public sector. Administration \& Society, 43, 842-868.

Spector P. (1986). Perceived control by employees: A meta-analysis of studies concerning autonomy and participation at work. Human Relations 39(11): 1005-1016.

Spreitzer GM. (1995). Psychological empowerment in the workplace: Dimensions, measurement, and validation. Academy of Management Journal 38(5): 1442-1465.

Spreitzer, G.; Porath, C.L.; Gibson, C.B. (2012). Toward human sustainability: How to enable more thriving at work. Organ. Dyn. 41, 155-162.

Stazyk, E. C. (2016). The prevalence of reinvention reforms in local governments and their relationship with organizational goal clarity and employee job satisfaction. Public Performance \& Management Review, 39(3), 701-727.

Suh, J., Harrington, J., \& Goodman, D. (2018). Understanding the Link Between Organizational Communication and Innovation: An Examination of Public, Nonprofit, and For-Profit Organizations in South Korea. Public Personnel Management, 47(2), 217-244.

Thaler, Richard, and Cass Sunstein. 2008. Nudge: Improving Decisions about Health, Wealth, and Happiness. London: Yale University Press.

Tims, M., Bakker, A.B. and Derks, D. (2015). "The impact of job crafting on job demands, job resources, and wellbeing", Journal of Occupational Health Psychology, Vol. 18 No. 2, p. 230.

Urbach, T., Fay, D. and Goral, A. (2010). Extending the Job Design Perspective on Individual Innovation: Exploring the Effect of Group Reflexivity. Journal of Occupational and Organizational Psychology, 83, 1053-64.

Valmohammadi, C., \& Ahmadi, M. (2015). The impact of knowledge management practices on organizational performance: A balanced scorecard approach. Journal of Enterprise Information Management, 28(1), 131159.

Van der Sluis LE. (2004). Designing the workplace for learning and innovation: Organizational factors affecting learning and innovation. Development and Learning in Organizations 18(5): 10-13.

Van der Doef M and Maes S. (2010). The job-demand-control-(support) model and psychological well-being. Work and Stress: An International Journal of Work, Health and Occupations 12(2): 87-114.

van de Ven, A.H. (1986). Central Problems in the Management of Innovation. Management Science, 32, 590-607.

Walker, R. M., Damanpour, F., \& Devece, C. A. (2011). Management innovation and organizational performance: The mediating effect of performance management. Journal of Public Administration Research and Theory, 21(2), 367-386.

Wang, S.; Noe, R.A. (2010). Knowledge sharing: A review and directions for future research. Hum. Resour. Manag. Rev. 20, 115-131.

Wani, T.A. and Ali, S.W. (2015). Innovation Diffusion theory. Journal of General Management Research.Vol. 3, issue 2.

West, M. A. (2002). Sparkling fountains or stagnant ponds: An integrative model of creativity and innovation implementation in work groups. Applied Psychology: An International Review, 51, 355-387.

West, M. A., Hirst, G., Richter, A., \& Shipton, H. (2004). Twelve steps to heaven: Successfully managing change through developing innovative teams. European Journal of Work and Organizational Psychology, 13, 269299.

Zaltman, G., Duncan, R. and Holbek, J. (1973). Innovations and Organizations. Wiley, New York. 